Brit. J. industr. Med., 1960, 17, 238.

\title{
THE ASSESSMENT OF ELECTROENCEPHALOGRAPHIC CHANGES AND MEMORY DISTURBANCES IN ACUTE INTOXICATIONS WITH INDUSTRIAL POISONS
}

\author{
BY \\ B. CHALUPA, J. SYNKOVÁ, and M. ŠEVČÍK \\ From the Clinic of Occupational Diseases and The Psychiatric Clinic, Brno, Czechoslovakia
}

(RECEIVED FOR PUBLICATION JUNE 25, 1959)

\begin{abstract}
A report is given of the results of the electroencephalogram (EEG) and of an experimental memory examination in a group of 22 cases of acute carbon monoxide and solvents poisoning of varying severity. An abnormal EEG recording, most often in the form of theta activity 5-6 sec., was found in 12 patients; memory disturbances were found in 13 cases. There was correlation between the results of the two examinations as well as with the clinical classification of the degree of intoxication. The methods are suitable for the solving of various theoretical and practical questions in industrial toxicology.
\end{abstract}

There is a need for methods of objective assessment of changes brought about in the central nervous system by toxic substances. A measure of the depth and extent of any injury would be of great importance in measuring disability. We have, therefore, tried to follow the signs of disturbances in the central nervous system due to industrial poisoning with the help of the electroencephalogram (EEG) and an experimental memory test.

EEG changes in acute carbon monoxide poisoning have received a good deal of attention and it is generally agreed that on recovery of consciousness the EEG returns to normal after the patient has recovered clinically (Noel, 1955).

Massman (1955) noted persistence of EEG changes for three weeks after intoxication; Noel (1955) found that the speed of the waves was inversely proportional to the degree of intoxication. The literature on poisoning by solvents is less extensive. Klimková-Deutschová and Lesný (1957) followed up cases of methyl chloride poisoning and found a relation between EEG changes and the clinical condition of the patient. Nissen (1953) described a case of acute trichloroethylene poisoning with evidence of an extrapyramidal lesion which was accompanied by slow EEG rhythm persisting for 15 months. Anderson (1957) found EEG changes in the form of theta waves in six out of 29 cases of chronic exposure to high concentrations of trichloroethylene. She was not convinced that the changes were related to poisoning even though in some cases the EEG returned to normal after the patient stopped working with trichloroethylene.

Disturbances of recall persisting for several months after carbon monoxide poisoning have been reported (Shillito, Drinker, and Shaughnessy, 1936; Störring, 1936 and Jéquier and Guerdjikoff, 1956). Defects of memory were noted in $38 \%$ of people chronically exposed to trichloroethylene (Grandjean, Münchinger, Turrian, Haas, Knoepfel, and Rosenmund, 1955) and have been found after methylchloride poisoning (Petráň, 1955). Pathological changes in the brain are well known after carbon monoxide poisoning and have been reported in rabbits after acute trichloroethylene poisoning (Bernardi, Penzani, and Luvoni, 1956).

\section{Cases Studied and Methods Applied}

We have examined 22 cases of acute poisoning by carbon monoxide and industrial solvents with an average age of 38 years. Of 12 cases of carbon monoxide poisoning nine were from illuminating gas and three from oven smoke. Of the solvents, trichloroethylene was the cause in six cases, methyl chloride in two and one each from methyl bromide and acetone. Eighteen of the cases were accidental (12 at home; six at work) and four were attempted suicides.

The patients were examined clinically from the 
medical, psychological and psychiatric aspects; the EEG examination was conducted on a 16-lead instrument (Kaiser) with the application of hyperventilation and photostimulation.

In the experimental examination of memory disturbances we applied a method used in our previous paper (Chalupa, 1958) to a population of 120 people including those with acute intoxication with various industrial poisons, chronic intoxication, a control group of normal persons and a group of persons with organic brain damage. Briefly the method consists of $(a)$ the assessment of spontaneous reproduction of 20 words recited from a list; (b) recognition of the same material interspersed with 10 new items of control; (c) reproduction of 30 word pairs, the two words standing in some relation to each other (window-light, injury-pain).

All items are presented acoustically.

Our rationale was that not all memory components are injured to the same degree through exposure to the toxic agent, so that it should be possible to differentiate pathological changes from natural inter-individual variations in memory performances. The average interval from the date of intoxication to the date of examination was three days (one to nine). At that time disturbances of consciousness had passed. The EEG examination followed on the next day.

The further examination depended upon the category of poisoning (light, moderate or severe) into which the patient had been placed. This depended on the concentration of the noxious agent, duration of exposure, the incidence and duration of unconsciousness, the clinical condition on admission, laboratory findings and course of recovery.

\section{Results}

EEG pathological changes were composed of middle voltage theta activity of 5-6 sec. of a rather regular type. The pattern was diffuse in three cases, localized in five. The theta activity was reflected in episodes localized into the anterior or posterior part of the brain in four cases; very rarely was it generalized. Episodes were more frequently found after hyperventilation or photostimulation. Generalized polymorphic dysrhythmia delta 2-3 sec. and theta 4-5 sec., with absence of normal rhythms,

was found in one case only. The distribution of the EEG findings can be seen in Table 1 .

Comparison of the EEG findings and the clinical classification shows a significant correlation. Of the mild cases five EEG's were normal and one atypical, but none was abnormal. Of the moderately severe cases three (Nos. 7,9 and 10) had normal EEG's and all of these were cases of carbon monoxide poisoning with less than three hours of unconsciousness. One (No. 21) of the severely poisoned cases had a normal EEG. This was an obese young girl poisoned with trichloroethylene and benzene.

TABLE 1

DISTRIBUTION OF THE EEG FINDINGS

\begin{tabular}{r|c}
\hline \multicolumn{1}{c|}{ Finding } & No. of Cases \\
\hline II. Normal & 9 \\
II. Atypical & 1 \\
IIV. Slightly abnormal & 2 \\
IV. Abnormal & 9 \\
V. Severely pathological & 1 \\
\hline
\end{tabular}

The average values of the memory tests in the acute intoxication cases compared with the control group of healthy persons show disturbances of logical memory and decrease of accordance in recognition, while the least injury was suffered by the mechanical memory (Table 2 ). The reproductive tendency and the percentage of false reproductions in the recognition test was, on the contrary, increased. This is in accordance with previous findings in acute intoxication.

The changed relations of various memory components suggest also the presence of a pathological process in individual cases. The comparison is undertaken with the help of a standard scale constructed from average values and standard deviations in a large population. We evaluated five pathognostic signs (the quantitative prevalence of reproductive tendency over the logical memory, over the accordance of recognition, over mechanical memory; prevalence of mechanical memory over logical memory; occurrence of false reproductions) whose frequency in the groups examined is shown in Table 3.

The results of the various examinations conducted are given in Table 4 . Taking into account the

TABLE 2

AVERAGE VALUES OF THE VARIOUS MEMORY COMPONENTS

\begin{tabular}{|c|c|c|c|c|c|c|}
\hline Group & Age & $\begin{array}{l}\text { Logical } \\
\text { Memory }\end{array}$ & $\begin{array}{l}\text { Accordance in } \\
\text { Recognition } \\
\%\end{array}$ & $\begin{array}{l}\text { Mechanical } \\
\text { Memory }\end{array}$ & $\begin{array}{c}\text { Reproductive } \\
\text { Tendency } \\
\%\end{array}$ & $\begin{array}{c}\text { False } \\
\text { Reproduction } \\
\%\end{array}$ \\
\hline $\begin{array}{l}\text { Acute intoxication ( } 22 \text { cases) } \\
\text { Normal persons ( } 20 \text { cases) }\end{array}$ & $\begin{array}{l}38 \cdot 05 \\
36 \cdot 1\end{array}$ & $\begin{array}{r}9 \cdot 5 \\
13 \cdot 0\end{array}$ & $\begin{array}{l}53 \cdot 9 \\
64 \cdot 5\end{array}$ & $\begin{array}{l}5 \cdot 7 \\
6 \cdot 3\end{array}$ & $\begin{array}{l}39 \cdot 8 \\
36 \cdot 25\end{array}$ & $\begin{array}{r}12 \cdot 7 \\
4 \cdot 0\end{array}$ \\
\hline
\end{tabular}

6 
TABLE 3

RESULTS OF THE MEMORY EXAMINATION BY THE GENERAL CLASSIFICATION

\begin{tabular}{l|c|c|c|c|c|c}
\hline $\begin{array}{c}\text { Number of } \\
\text { Patbognostic Signs }\end{array}$ & 0 & 1 & 2 & 3 & 4 & 5 \\
\hline $\begin{array}{l}\text { Acute intoxication } \\
\text { (22 cases) }\end{array}$ & 2 & 3 & 4 & 8 & 5 & - \\
$\begin{array}{l}\text { Normal persons } \\
\text { (20 cases) }\end{array}$ & 8 & 6 & 6 & - & - & - \\
\hline
\end{tabular}

variations in normal population we regard the findings in nine persons examined as within normal limits, while 13 are pathological. Memory disturbances increase with the degree of clinical intoxication. Contrary to the EEG findings some of the mild intoxications had memory disturbances (Cases 4 and 6), otherwise the same is valid for the EEG in comparison with clinical criteria, namely that carbon monoxide intoxication with a short period of unconsciousness was not necessarily followed by pathological changes when adequately treated (Cases 7,9 and 10). We had one case of a severe peroral trichloroethylene intoxication with a long period of unconsciousness without memory disturbance (Case 22).

Notwithstanding certain differences, general accord can be found between the EEG findings and the memory examination in acute intoxications (Table 5). Differences were found in four cases, two patients with mild intoxication (Cases 4 and 6) who had memory disturbance but a normal EEG
TABLE 5

COMPARISON OF THE EEG FINDINGS AND THE RESULTS OF THE MEMORY EXAMINATION WITH THE CLINICAL CLASSIFICATION OF THE DEGREE OF INTOXICATION

\begin{tabular}{l|c|c}
\hline & $\begin{array}{c}\text { EEG Examination } \\
\text { Pathological } \\
\text { Findings }\end{array}$ & $\begin{array}{c}\text { Memory Examination } \\
\text { Pathological } \\
\text { Findings }\end{array}$ \\
\hline $\begin{array}{l}\text { Mild intoxication } \\
\text { (6 cases) } \\
\text { Moderate intoxication } \\
\text { (10 cases) }\end{array}$ & 0 & 2 \\
$\begin{array}{l}\text { Sere intoxication } \\
\text { (6 cases) }\end{array}$ & 7 & 6 \\
\hline Total (22 cases) & 5 & 5 \\
\hline
\end{tabular}

and two patients with severe intoxication (Cases 21 and 22) who had either normal EEG and abnormal memory examination or vice versa.

Of the patients with a pathological EEG, $83 \%$ had memory disturbances, whereas for patients with normal EEG the figure was $30 \%$. The coefficient between the two findings is $\mathrm{r}=+0.472 \pm 0.112$ which is four times the standard deviation and therefore statistically significant. While the agreement between the two examinations seems assured, in practice the methods will support each other.

In view of the small number of cases investigated, the statistical treatment of sub-divisions according to toxic substance would present difficulties. On the whole it would seem from our material that the relations between the degree of intoxication, EEG recording, and degree of memory disturbance are

TABLE 4

RESULTS OF VARIOUS EXAMINATIONS CONDUCTED IN CASES OF ACUTE INTOXICATION

\begin{tabular}{|c|c|c|c|c|c|c|c|c|c|c|}
\hline $\begin{array}{l}\text { Case } \\
\text { No. }\end{array}$ & Age & Sex & Toxic Agent & $\begin{array}{c}\text { Mode of } \\
\text { Assimilation }\end{array}$ & $\begin{array}{l}\text { Nature of } \\
\text { Accident }\end{array}$ & $\begin{array}{c}\text { Loss } \\
\text { of } \\
\text { Conscious- } \\
\text { ness }\end{array}$ & $\begin{array}{c}\text { Degree } \\
\text { of } \\
\text { Intoxica- } \\
\text { tion }\end{array}$ & $\begin{array}{c}\text { EEG } \\
\text { Classifica- } \\
\text { tion } \\
\text { (Table 1) }\end{array}$ & $\begin{array}{c}\text { Memory } \\
\text { Dis- } \\
\text { turbance } \\
\text { Classifica- } \\
\text { tion } \\
\text { (Table 3) }\end{array}$ & $\begin{array}{l}\text { Clinical } \\
\text { Sequelae }\end{array}$ \\
\hline $\begin{array}{l}1 \\
2 \\
3 \\
4 \\
5 \\
6\end{array}$ & $\begin{array}{l}51 \\
16 \\
72 \\
36 \\
57 \\
19\end{array}$ & $\begin{array}{l}\mathbf{M} \\
\mathbf{M} \\
\mathbf{F} \\
\mathbf{F} \\
\mathbf{M} \\
\mathbf{M}\end{array}$ & $\begin{array}{l}\text { Carbon monoxide } \\
\text { Carbon monoxide } \\
\text { Carbon monoxide } \\
\text { Carbon monoxide } \\
\text { Trichloroethylene } \\
\text { Acetone }\end{array}$ & $\begin{array}{l}\text { Inhalation } \\
\text { Inhalation } \\
\text { Inhalation } \\
\text { Inhalation } \\
\text { Ingestion } \\
\text { Inhalation }\end{array}$ & $\begin{array}{l}\text { Home accident } \\
\text { Home accident } \\
\text { Home accident } \\
\text { Home accident } \\
\text { Home accident } \\
\text { Industrial }\end{array}$ & $\begin{array}{l}\text { No } \\
\text { No } \\
\text { No } \\
\text { No } \\
\text { No } \\
\text { No }\end{array}$ & $\begin{array}{l}\text { Mild } \\
\text { Mild } \\
\text { Mild } \\
\text { Mild } \\
\text { Mild } \\
\text { Mild }\end{array}$ & $\begin{array}{l}\text { I } \\
\text { I } \\
\text { II } \\
\text { I } \\
\text { I } \\
\text { I }\end{array}$ & $\begin{array}{l}0 \\
2 \\
1 \\
4 \\
1 \\
4\end{array}$ & $\begin{array}{l}\mathbf{0} \\
\mathbf{0} \\
\mathbf{0} \\
\mathbf{0} \\
\mathbf{0} \\
\mathbf{0}\end{array}$ \\
\hline $\begin{array}{r}7 \\
8 \\
9 \\
10 \\
11 \\
12 \\
13 \\
14 \\
15 \\
16\end{array}$ & $\begin{array}{l}49 \\
18 \\
21 \\
24 \\
30 \\
22 \\
35 \\
47 \\
40 \\
51\end{array}$ & $\begin{array}{l}\mathbf{F} \\
\mathbf{F} \\
\mathbf{F} \\
\mathbf{M} \\
\mathbf{M} \\
\mathbf{F} \\
\mathbf{M} \\
\mathbf{M} \\
\mathbf{M} \\
\mathbf{M}\end{array}$ & $\begin{array}{l}\text { Carbon monoxide } \\
\text { Carbon monoxide } \\
\text { Carbon monoxide } \\
\text { Carbon monoxide } \\
\text { Trichloroethylene } \\
\text { Trichloroethylene } \\
\text { Trichloroethylene } \\
\text { Methylchloride } \\
\text { Methylchloride } \\
\text { Methylbromide }\end{array}$ & $\begin{array}{l}\text { Inhalation } \\
\text { Inhalation } \\
\text { Inhalation } \\
\text { Inhalation } \\
\text { Ingestion } \\
\text { Ingestion } \\
\text { Inhalation } \\
\text { Inhalation } \\
\text { Inhalation } \\
\text { Inhalation }\end{array}$ & $\begin{array}{l}\text { Suicidal } \\
\text { Suicidal } \\
\text { Home accident } \\
\text { Home accident } \\
\text { Home accident } \\
\text { Home accident } \\
\text { Industrial } \\
\text { Industrial } \\
\text { Industrial } \\
\text { Industrial }\end{array}$ & $\begin{array}{l}\text { Yes } \\
\text { Yes } \\
\text { Yes } \\
\text { Yes } \\
\text { No } \\
\text { No } \\
\text { Yes } \\
\text { No } \\
\text { No } \\
\text { No }\end{array}$ & $\begin{array}{l}\text { Moderate } \\
\text { Moderate } \\
\text { Moderate } \\
\text { Moderate } \\
\text { Moderate } \\
\text { Moderate } \\
\text { Moderate } \\
\text { Moderate } \\
\text { Moderate } \\
\text { Moderate }\end{array}$ & $\begin{array}{l}\text { I } \\
\text { IV } \\
\text { I } \\
\text { I } \\
\text { IV } \\
\text { IV } \\
\text { III } \\
\text { IV } \\
\text { IV } \\
\text { III }\end{array}$ & $\begin{array}{l}2 \\
3 \\
0 \\
1 \\
3 \\
4 \\
4 \\
2 \\
3 \\
3 \\
3\end{array}$ & $\begin{array}{l}\mathbf{0} \\
\mathbf{0} \\
\mathbf{0} \\
\mathbf{0} \\
\mathbf{0} \\
+ \\
+ \\
+ \\
+ \\
++\end{array}$ \\
\hline $\begin{array}{l}17 \\
18 \\
19 \\
20 \\
21 \\
22\end{array}$ & $\begin{array}{l}40 \\
17 \\
57 \\
\\
54 \\
19 \\
62\end{array}$ & $\begin{array}{l}\mathbf{M} \\
\mathbf{M} \\
\mathbf{F} \\
\mathbf{M} \\
\mathbf{F} \\
\mathbf{M}\end{array}$ & $\begin{array}{l}\text { Carbon monoxide } \\
\text { Carbon monoxide } \\
\text { Carbon monoxide } \\
\text { Carbon monoxide } \\
\text { Trichloroethylene } \\
\text { Trichloroethylene }\end{array}$ & $\begin{array}{l}\text { Inhalation } \\
\text { Inhalation } \\
\text { Inhalation } \\
\text { Inhalation } \\
\text { Ingestion } \\
\text { Ingestion }\end{array}$ & $\begin{array}{l}\text { Suicidal } \\
\text { Home accident } \\
\text { Home accident } \\
\text { Industrial } \\
\text { Suicidal } \\
\text { Home accident }\end{array}$ & $\begin{array}{l}\text { Yes } \\
\text { Yes } \\
\text { Yes } \\
\text { Yes } \\
\text { Yes } \\
\text { Yes }\end{array}$ & $\begin{array}{l}\text { Severe } \\
\text { Severe } \\
\text { Severe } \\
\text { Severe } \\
\text { Severe } \\
\text { Severe }\end{array}$ & $\begin{array}{l}\text { IV } \\
\text { IV } \\
\text { V } \\
\text { IV } \\
\text { I } \\
\text { IV }\end{array}$ & $\begin{array}{l}3 \\
3 \\
3 \\
3 \\
4 \\
4 \\
2\end{array}$ & $\begin{array}{c}0 \\
0 \\
\text { death } \\
\text { on } \begin{array}{c}32 \text { nd day } \\
++ \\
+ \\
0\end{array}\end{array}$ \\
\hline
\end{tabular}

Note.-Sequelae of intoxication:

$+\quad=$ minor passing post-intoxication symptomatology (headache, vertigo, insomnia)

$++=$ lasting sequelae of organic character. 
more pronounced in carbon monoxide than in the solvent intoxications. Further investigations in this respect are in progress.

The solvent intoxications, as measured by our two examinations, are more severe than those by carbon monoxide, which is rather surprising in view of the fact that they were followed by loss of consciousness in three cases only, while it occurred in eight of the carbon monoxide intoxications. This is striking in the moderate group, where among four carbon monoxide intoxications only one EEG finding was abnormal, while the six solvent cases all had abnormal EEG values. Pathological EEG findings occur as a rule in severe carbon monoxide intoxication with a high concentration of the noy ious agent and a long sojourn in it. Memory disturbances follow the same pattern.

Quantitative differences in the findings in our group may be explained mostly by efficient and early hospital care in the acute carbon monoxide intoxications, in contrast to the prolonged noxious effects in the cases of solvent poisoning. Qualitative differences could not be ascertained, which is reflected in the consistency of the central nervous system injury by various noxious agents.

No constant relation was found between the EEG and memory examinations on the one hand and the loss of consciousness on the other; this is understandable when we consider the severe solvent intoxications which rarely led to loss of consciousness. The time of exposure seems to be of more importance, as pathological findings were more numerous with prolonged exposure.

Most patients recovered clinically within a week, a fortnight being exceptional. One patient (Case 19) died on the 32 nd day after a period of temporary improvement between the fifth and 10th day. Serious clinical sequelae were found in two patients (Cases 16 and 20), whose working ability was affected. Minor sequelae followed in five patients.
Follow-up EEG examinations did not show any improvement in some cases for as long as a year after the clinical picture had become normal. This persistence of abnormal findings is described in the literature on carbon monoxide, but less so in solvents intoxication.

The memory tests were repeated while using new material of equal value. Results showed improvement of the logical memory and of recognition, the mechanical memory did not improve.

Neurological findings were mostly normal in the solvents intoxication while some were pathological in the carbon monoxide group.

\section{Conclusion}

Electroencephalography and the experimental memory tests may be of value in the assessment of the degree of intoxication and of the eventual sequelae when treating injuries from carbon monoxide, trichloroethylene, methylchloride, methylbromide and other toxic agents met with in industry. The methods were very sensitive and hence well suited for the solving of theoretical and practical questions of industrial toxicology, where an objective evaluation of injuries to the central nervous system is required.

\section{REFERENCES}

Anderson, A. (1957). Acta med. scand. 157, Suppl. 323. Bernardi, L., Penzani, B., and Luvoni, R. (1956). Rass. Med. industr.

Chalupa, B. (1958). Čsl. Psychol., 2, 356.

Grandjean, E., Münchinger, R., Turrian, V., Haas, P. A., Knoepfel, H.-K., and Rosenmund, H. (1955). Brit. J. industr. Med., $12,131$.

Jéquier, ${ }_{76,180 \text {. }}$ and Guerdjikoff, C. (1956). Rev. méd. Suisse rom.,

Klimková-Deutschová, E., and Lesný, I. (1957). Pracov. Lék., 9, 298.

Massman, H. (1955). Electroenceph. clin. Neurophysiol., 7, 661.

Nissen, T. (1953). Praxis. 42, 881.

Noel, G. (1955). Arch. Belges Méd. soc., 13, 689

Petran, V. (1955). Neurol. psychiat., čsl., 18, 14. Amer. med. Ass., 106, 669 .

Amer. med. Ass., 106, 669.
Störring, G. (1936). Gedächtnisverlust durch Gasvergiftung. Leipzig 